\title{
IAMJ
}

INTERNATIONAL

AYURVEDIC

MEDICAL JOURNAL

ISSN: 23205091

Impact Factor: 5.344

\section{MANAGEMENT OF ASRIGDARA WITH KUTAJASHTAKA AVALEHA AND YASHTIMADHU GHRITA MATRA BASTI - AN OPEN LABEL, DOUBLE ARM, RANDOMIZED CLINICAL TRIAL}

\author{
$\underline{\text { Stuti Sharma }}^{1}, \underline{\text { Meenakshi Pandey }}^{2}$
}

${ }^{1}$ M.S. (Ayu.) Scholar, ${ }^{2}$ Assistant Professor

Department of Stri Roga and Prasuti Tantra, All India Institute of Ayurveda, Sarita Vihar, New Delhi, India

Corresponding Author: stuti.sharma0904@gmail.com

\section{https://doi.org/ $10.46607 /$ iamj2008102020}

(Published online: October 2020)

Open Access

(C) International Ayurvedic Medical Journal, India 2020

Article Received: 29/09/2020 - Peer Reviewed: 02/10/2020 - Accepted for Publication: 04/10/2020

\section{Check for updates}

\begin{abstract}
Introduction: The word Asrigdara explains about prolonged, cyclic or acyclic excessive menstrual bleeding in Ayurveda. 9-14\% of women in their reproductive age lose $80 \mathrm{ml}$ of blood in each cycle. It is the most common cause of Anemia. Traditionally, Heavy Uterine Bleeding is managed with medical therapy and surgical intervention with associated side effects. But due to limitation of medical therapy as well as surgical interventions, it becomes the necessity of time to find out a permanent, easy, effective and less side effect producing care which can be easily administered and accepted by the patient. Objective: To evaluate the clinical efficacy of Kutajashtaka Avaleha orally and combination of Kutajashtaka Avaleha and Yashtimadhu Ghrita matra basti in combating the signs and symptoms of Asrigdara. Materials and Methods: 56 patients were selected from the Stri Roga and Prasuti Tantra OPD, All India Institute of Ayurveda, New Delhi and randomly divided into 2 groups. Group A was administered with Kutajashtaka Avaleha orally regularly for the period of 3 months with the doses of $5 \mathrm{gm}$ BD after meal with water, while in Group B, Combination of Yashtimadhu Ghrita Matra Basti (60 ml for 7 days in 3 consecutive cycles after meal through rectal route after 7th day of menses) for 3 months and Kutajashtaka Avaleha was given and the follow up period of 1 month without medication was same for both the groups. Results: Kutajashtaka Avaleha orally alone and Combination of Yashtimadhu Ghrita Matra Basti \& Kutajashtaka Avaleha oral both gave statistically highly Significant results $(\mathrm{P}<0.001)$ but with better results when the treatment was combined and Markedly
\end{abstract}


Improved (51-75\% relief) the signs and symptoms. Conclusion: Combination of Yashtimadhu Ghrita Matra Basti \& Kutajashtaka Avaleha oral gave more statistically significant results than Kutajashtaka Avaleha orally alone. No adverse effects were reported during the entire trial period.

Keywords: Ayurveda, Asrigdara, Kutajashtaka Avaleha, Matra Basti. Yashtimadhu Ghrita.

\section{INTRODUCTION}

$28 \%$ of the female population consider their menstruation excessive and will plan their social activities around their menstrual cycle $1.9-14 \%$ of women in their reproductive age lose $80 \mathrm{ml}$ of blood in each cycle. In its multiple country study, World Health Organization (WHO) identified the prevalence of three-month severe bleeding as $8-27 \% \%^{2}$. If the menstrual cycle turns to be abnormal with excessive and prolonged bleeding associated with pain or appearing at irregular intervals is suggestive of some underlying pathology. It is the most common cause of Anemia and Dysmenorrhea ${ }^{3}$. Asrigdara is one amongst extensive range of occurrence. The word Asrigdara explains about prolonged, cyclic or acyclic excessive menstrual bleeding in Ayurved ${ }^{4}$ Acharya Sushruta has said that Prolonged and excessive menstrual bleeding along with Pain and Body ache are the clinical features of Asrigdara ${ }^{5}$. Asrigdara is a symptom of various Yonivyapadas including Pittaja Yonivyapad, Asrija Yonivyapad, Lohit-kshara Yonivyapad, Paripluta Yobivyapad and Rakta-yoni and Artava-dushti including Kunapa-Gandhi and Pittaja Artava-dushti. It is also related to Parisravi Jatharini and Raktarbuda. It is a Rakta-Pradoshaja Vikara due to Pittavritta ApanaVayu causes vitiation of RaktaDhatu ${ }^{6}$. Ashtanga Sangraha has explained Raktayoni and said Asrigdara and pradara as its synonyms ${ }^{7}$. Traditionally, heavy Uterine Bleeding is managed with medical therapy with associated side effects and if unsuccessful is followed by surgical intervention ${ }^{8}$. Therefore, it becomes the necessity of time to find out a permanent, easy, effective and less side effect producing care which can be easily administered and accepted by the patient. So many preparations have been mentioned in our texts for the treatment of Asrigdara. These are Pitta-Kapha shamaka and shodhaka, Raktashodhaka and stambhaka, Garbhashaya Balya and Vatanulomana. Samprapti Vighatana and effective control and cure in the Asrigdara are the main aims with which the drugs were selected for the present study. No previous work is done on these two formulations. So, formulations namely Kutajashtaka Avaleha ${ }^{9}$ and Yashtimadhu Ghrita Matra Basti ${ }^{10}$ have been selected to work upon. Objective-To evaluate the clinical efficacy of Kutajashtaka Avaleha orally and combination of Kutajashtaka Avaleha and Yashtimadhu Ghrita matra basti in combating the symptoms of heavy and prolonged menstrual bleeding or intermenstrual bleeding in cases of Asrigdara.

\section{Materials}

Preparation of Trial drug-All the drugs were collected and authenticated from reliable sources and standardization was done as per API guidelines. Kutajashtaka Avaleha and Yashtimadhu Ghrita were made in GMP certified Pharmacy. Selection of route of administration of drug- Basti therapy is the best treatment for Vikrita Apanavayu and Artavavikara. Thus, it normalizes the functions of different Srotasa as it clears the obstruction and allows freely movement of bioenergetics through the channels. Thus, it acts as curative, rejuvenative and preventive measure. It cures all kinds of diseases due to its varied pharmacodynamics and various kinds of drugs used in its preparation. Ethical approval-The clinical trial was approved by the Institutional Ethics Committee of All India Institute of Ayurveda, Sarita Vihar, New Delhi. (IEC-AIIA/2018PG-104). Trial Registration-Study was registered in Clinical Trials Registry of India. (CTRI/2019/08/020743)

\section{Methods}

Study Design-An open labelled, double arm, interventional, prospective randomized clinical trial of sample size 56 with duration 3 months.

Selection of Patients-Total 56 patients were selected from the SRPT OPD, AIIA, New Delhi and randomly 
divided into 2 groups. Patients were selected on the basis of symptoms - Heavy and prolonged menstrual bleeding or intermenstrual bleeding.

Informed Consent: The purpose of the study, nature of the selected drugs, the procedures to be carried out and the potential risks and benefits were explained to the patients in detail in non- technical terms and bilingual. Thereafter their written consent was taken before the treatment. A suitable case report form (CRF) was filled for the specific assessment outline and entered in electronic format designed in Microsoft Excel.

Inclusion Criteria-(i) Women of reproductive age group 18-45years, (ii) Patients with symptoms of heavy and prolonged menstrual bleeding or intermenstrual bleeding, (iii) Patients who were interested and gave their written consent for the study work, (iv)Patients who were willing to go for relevant investigations. $\boldsymbol{E x}$ clusion Criteria-(i) Patients with any diagnosed uterine organic pathology like Uterine Fibroid, Adenomyosis, chronic Tubo-ovarian mass. (ii) Patients with systemic diseases like hypertension, diabetes mellitus, congestive cardiac failure etc. (iii) Patients with coagulopathy, liver and thyroid dysfunction etc. (iv) Patients with malignancy or undiagnosed neoplasm. (v) Patients with history of recent abortion. (vi) patients with active genital tuberculosis. (vii) Bleeding from the polyps and erosion. (viii) IUCD in utero, pelvic endometriosis. (ix) $\mathrm{Hb}<8 \mathrm{gm} / \mathrm{dl}$. (x) Patients with history of chronic constipation.

Diet - Diet pattern was same for both the groups. Patients were advised to take routine diet and to avoid excessive oily, sweet, spicy, fried food, curd, fermented food, over diet and sour items. To consume more green vegetables, fruits and milk.

Grouping and Drug delivery regimen-Equal number of samples were taken in two groups by randomization. Group A was administered with Kutajashtaka avaleha orally regularly for the period of 3 months with the doses of $5 \mathrm{gm} \mathrm{BD}$ after meal with water. Group B was administered with the combination of Kutajashtaka avaleha and Yashtimadhu Ghrita matra basti $(60 \mathrm{ml}$ for 7 days in 3 consecutive cycles after meal through rectal route after 7 th day of menses) for 3 months.

\section{Outcome Measures-}

Criteria for assessment (Subjective parameters)-(i) Duration of bleeding. (ii)Inter menstrual period. (iii)Lower abdominal pain. (iv) Low backache. (v)Amount of blood loss.

Table 1: Grading of the subjective parameters

\begin{tabular}{|c|c|c|c|c|}
\hline $\begin{array}{l}\text { Subjective Parame- } \\
\text { ters }\end{array}$ & $\begin{array}{l}\text { Grade } 0 \text { (Nor- } \\
\text { mal) }\end{array}$ & Grade 1 (Mild) & Grade 2 (Moderate) & Grade 3 (Severe) \\
\hline Duration of bleeding & Less than 5 days & 5-7 days & 8-10 days & Greater than 10 days \\
\hline Intermenstrual period & 26-30 days & 21-25 days & 16-20 days & Less than 15 days/Irregular \\
\hline $\begin{array}{l}\text { Lower Abdominal } \\
\text { pain }\end{array}$ & 0 (No pain) & $\begin{array}{l}1-3 \text { in VAS (Mild } \\
\text { pain) }\end{array}$ & $\begin{array}{l}4-7 \text { in VAS (Moderate } \\
\text { pain) }\end{array}$ & 8-10 in VAS (Severe pain) \\
\hline Low Backache & 0 (No pain) & $\begin{array}{l}\text { 1-3 in VAS (Mild } \\
\text { pain) }\end{array}$ & $\begin{array}{l}4-7 \text { in VAS (Moderate } \\
\text { pain) }\end{array}$ & 8-10 in VAS (Severe pain) \\
\hline
\end{tabular}


Amount of Blood loss (Menstrual Pictogram) ${ }^{11}$
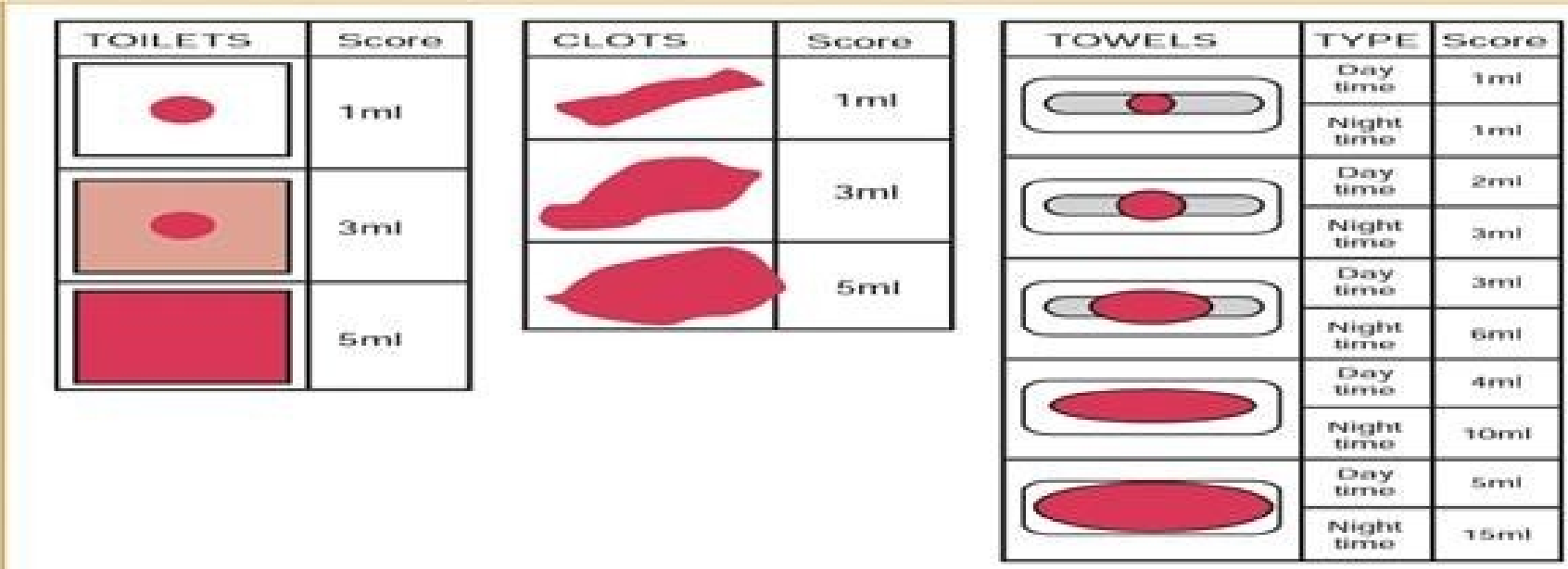

Table 2: A numerical scoring system was devised to coincide with the amount of blood lost in Menstrual Pictogram

\begin{tabular}{|l|l|l|l|l|}
\hline & Remarks & Light & Moderate & Heavy \\
\hline Toilets & Volume of blood lost in the toilet when changing sanitary wear. & $1(1 \mathrm{ml})$ & $3(3 \mathrm{ml})$ & $5(5 \mathrm{ml})$ \\
\hline Clots & Amount of Blood lost in the form of Clots & $1(1 \mathrm{ml})$ & $3(3 \mathrm{ml})$ & $5(5 \mathrm{ml})$ \\
\hline Towels & Amount of Blood soaked in the towel/Sanitary Pad. & $1(1 \mathrm{ml})$ & $5(5 \mathrm{ml})$ & $20(20 \mathrm{ml})$ \\
\hline
\end{tabular}

Matra Basti Assessment parameters ${ }^{12}$-Samyak Yoga, Ayoga and Atiyoga Lakshanas of Matra basti were assessed in 3 consecutive cycles. Matra Basti was performed in following three steps- Poorva karma- Local Abhyanga with Bala taila for 20 minutes followed by Swedana by Nadi sweda for 20 minutes. Pradhan Karma- slowly and steadily $60 \mathrm{ml}$ Yashtimadhu Ghrita was administered through rectal route with plastic syringe and rubber catheter and patient was asked to inhale and exhale deeply and keep her as relaxed as possible. Pashchata Karma- patient was tapped on the back and legs were bent, asked her to lie down supine for at least 15 minutes and hot water bag was given for Swedana purpose. Statistical Analysis-The SPSS statistical software was used for statistical analysis. The mean, standard deviation, standard error will be calculated for each group. Statistical analysis was done by applying 'Unpaired t-test' to BT and AT assessment scores. Mean \% reduction in subjective parameters for both the groups was calculated and Obtained results were measured according to the grades as Complete remission $100 \%$, marked improvement $76-99 \%$, moderate improvement $51-75 \%$, mild improvement $26-50 \%$ and no improvement $<25 \%$ relief in the sign and symptoms.

\section{Observations and Results}

Status of enrolled patients: Total diagnosed 62 patients having Sign and symptoms of Asrigdara were registered for the clinical trial, out of which 56 patients (28 patients in each group) completed the clinical study with follow up and 6 patients ( 2 in Group A and 4 in Group B) discontinued the treatment due to personal reasons.

Demographic Profile: Demographic data of enrolled patients $(\mathrm{n}=56)$ viz. distribution of patients according to age, marital status, educational status, socio-economic status, occupation, habitat and religion are depicted in Table 3. 
Table 3: Demographic Data of enrolled patients-

\begin{tabular}{|c|c|c|c|}
\hline Data & Criteria & $\mathrm{N}=56$ & Percentage \\
\hline \multirow[t]{3}{*}{ Age } & $18-26$ yrs & 10 & $17.86 \%$ \\
\hline & $27-36$ yrs & 21 & $37.50 \%$ \\
\hline & $37-45 \mathrm{yrs}$ & 25 & $44.64 \%$ \\
\hline \multirow[t]{3}{*}{ Marital status } & Married & 48 & $85.71 \%$ \\
\hline & Unmarried & 7 & $12.59 \%$ \\
\hline & Widow & 1 & $1.79 \%$ \\
\hline \multirow[t]{6}{*}{ Educational status } & Uneducated & 9 & $16.07 \%$ \\
\hline & Primary & 7 & $12.50 \%$ \\
\hline & Secondary & 18 & $32.14 \%$ \\
\hline & Higher secondary & 15 & $26.78 \%$ \\
\hline & Graduation & 6 & $10.72 \%$ \\
\hline & Post-Graduation & 1 & $1.79 \%$ \\
\hline \multirow[t]{4}{*}{ Socio-economic status } & Lower middle & 21 & $37.50 \%$ \\
\hline & Middle & 27 & $48.21 \%$ \\
\hline & Upper middle & 5 & $8.93 \%$ \\
\hline & Rich & 3 & $5.36 \%$ \\
\hline \multirow[t]{2}{*}{ Occupation } & Housewife & 39 & $69.64 \%$ \\
\hline & Working/Job & 17 & $30.36 \%$ \\
\hline \multirow[t]{2}{*}{ Habitat } & Rural & 13 & $23.21 \%$ \\
\hline & Urban & 43 & $76.79 \%$ \\
\hline \multirow[t]{2}{*}{ Religion } & Hindu & 50 & $89.28 \%$ \\
\hline & Muslim & 6 & $10.72 \%$ \\
\hline
\end{tabular}

Present Menstrual history- $66.07 \%$ had regular cycle and $33.93 \%$ had irregular cycle. $58.93 \%$ patient had moderate blood loss and $41.07 \%$ were having excessive blood loss. $66.07 \%$ patient had interval of menstrual period $16-20$ days and $62.5 \%$ were having painless menses.

Chief Complaints-Duration of Bleeding: 53.57\% were having duration of bleeding for 8-10 days, while each $23.21 \%$ were having 5-7 days and greater than 10 days respectively.

Intermenstrual Period: $66.07 \%$ were having their intermenstrual period of $16-20$ days and $33.93 \%$ were having less than 15 days or irregular intermenstrual period.
Lower abdominal pain: $58.93 \%$ were having moderate lower abdominal pain and $28.57 \%$ were having severe lower abdominal pain.

Low Backache: $60.71 \%$ were having moderate low backache, 33.93\% were having severe backache.

Amount of blood loss: $58.93 \%$ were having moderate bleeding during their menstruation and $41.07 \%$ were having heavy bleeding during their periods. 53.57\% were having heavy clots during their menses.

Effect of Therapy- Graph 1 \& Graph 2 showing mean reduction in subjective parameters in group $\mathrm{A}$ and group B respectively, depicted here- 
Graph 1Mean Reduction in Subjective parameters in Group A

(BT Vs AT)

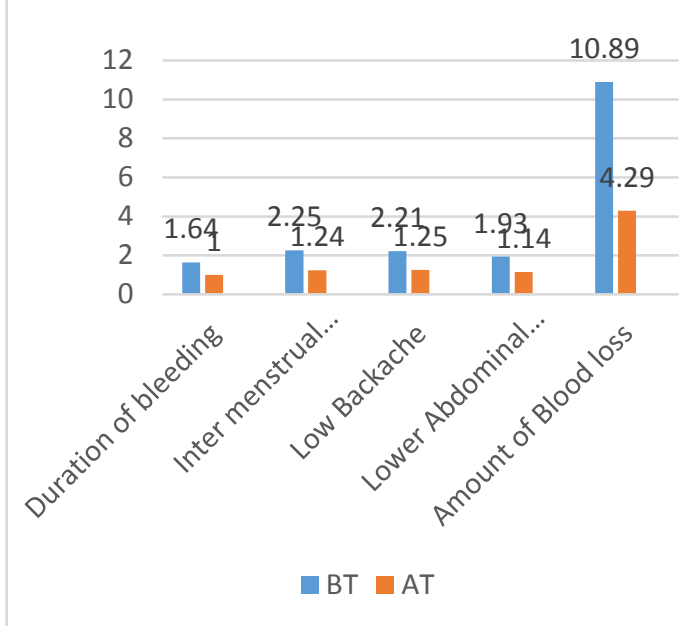

Effect of therapy on subjective parameters (between the groups)-

Duration of bleeding: When compared between the two groups, mean difference of duration of bleeding from BT to AT in group B is 0.93 , which is greater than group A i.e. 0.64 with mean difference of -0.29 . It reveals that Duration of bleeding is significantly reduced in group B as compared to group $\mathrm{A}$ and it was found statistically significant $(\mathrm{t}=2.44, \mathrm{df}=54, \mathrm{p}<0.05)$.

Intermenstrual period: When compared between the two groups, mean difference of Intermenstrual period from BT to AT in group B is 0.36 , which is greater than group A i.e. 0.04 with mean difference of -0.32 . It reveals that Intermenstrual bleeding is significantly reduced in group B as compared to group A and it was found statistically significant $(\mathrm{t}=3.25, \mathrm{df}=54, \mathrm{p}<0.05)$. Lower Abdominal pain: When compared between the two groups, mean difference of lower abdominal pain
Graph 2-

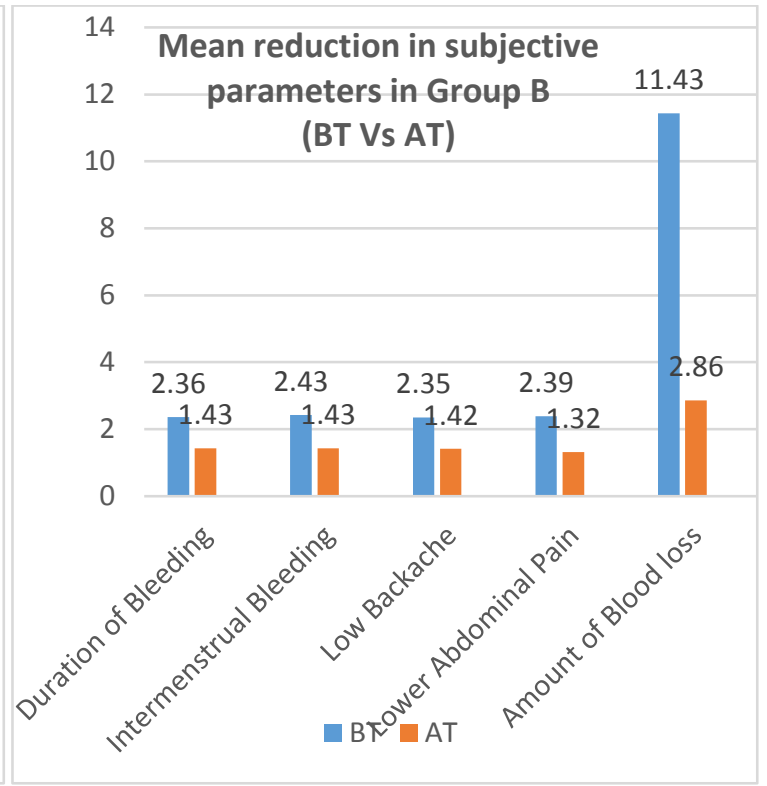

from BT to AT in group B is 1.07 , which is greater than group A i.e. 0.79 with mean difference of -0.28 . It reveals that Lower abdominal pain is significantly reduced in group B as compared to group $\mathrm{A}$ and it was found statistically significant $(\mathrm{t}=2.41, \mathrm{df}=54, \mathrm{p}<0.05)$.

Low backache: When compared between the two groups, it was observed that with reference to low backache, treatment given in both the respective groups is equally effective and therefore none of the 2 group is superior. $(\mathrm{t}=0.38, \mathrm{df}=54, \mathrm{p}>0.05)$.

Amount of blood loss: When compared between the two groups, Mean difference of amount of blood loss from BT to AT in group B is 8.57, which is greater than group A i.e. 6.60 with mean difference of -1.96 . It reveals that Amount of blood loss is significantly reduced in group B as compared to group A and it was found statistically significant $(\mathrm{t}=1.15, \mathrm{df}=54, \mathrm{p}<0.05)$ 
Graph 3: Mean reduction in subjective parameters (Between the groups)- BT vs AT

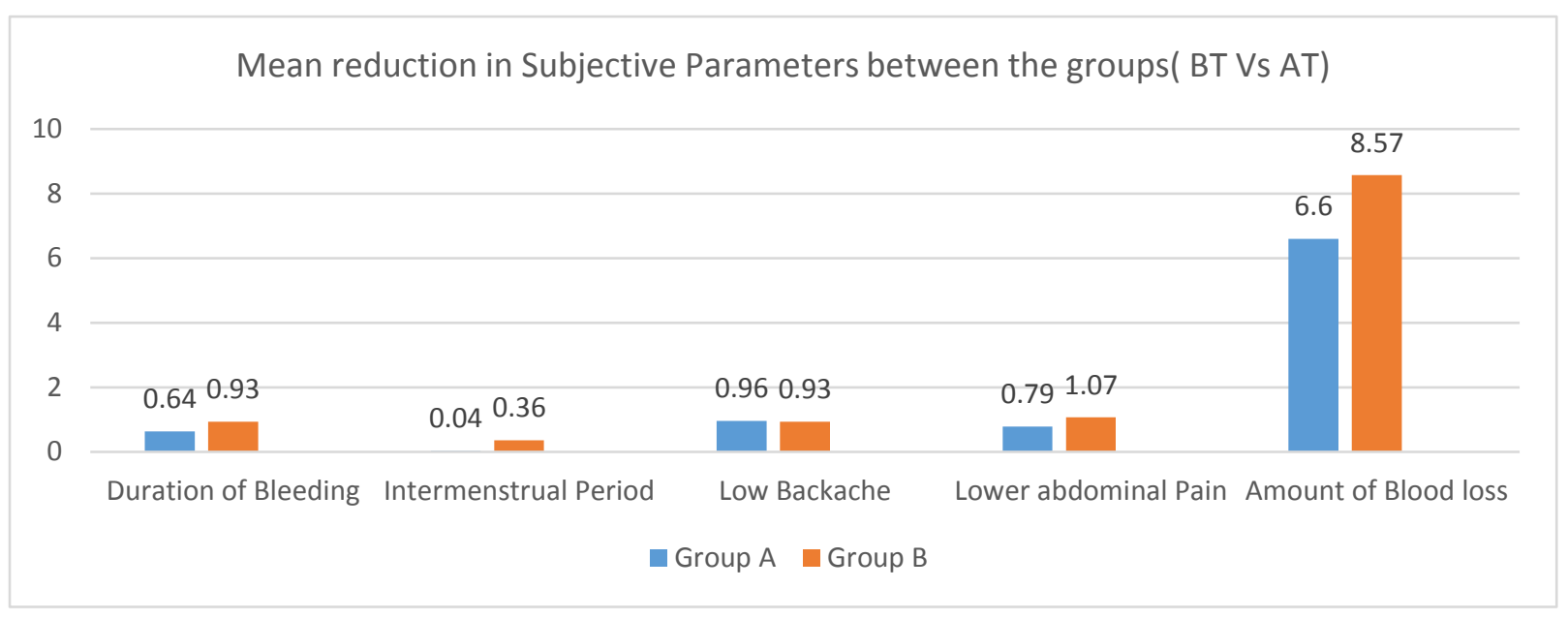

Overall Effect of therapy (By Calculating mean of \% reduction in all 5 subjective parameters)- Group A$58.40 \%$, Group B-63.75\%- It is clearly seen that the treatment given to the patients in both the Groups has Markedly Improved (51-75\% relief in sign and symptoms) the signs and symptoms of Asrigdara.

Graph 4: Overall effect of therapy between the groups (BT vs Follow up)

\begin{tabular}{|l|l|}
\hline & Overall effect of therapy between the groups \\
\hline $66.00 \%$ & \multicolumn{2}{|c|}{$63.75 \%$} \\
\hline $64.00 \%$ & \\
\hline $62.00 \%$ & \\
\hline $60.00 \%$ & $58.40 \%$ \\
\hline $58.00 \%$ & Group B \\
\hline $56.00 \%$ & Group A \\
\hline $54.00 \%$ & G \\
\hline
\end{tabular}

\section{DISCUSSION}

Asrigdara is a disease manifesting as excessive bleeding per vaginum. The majority of the Lakshanas of Asrigdara are due to aggravated Vayu, withholding the Rakta (blood) \& Pitta vitiated due to Nidana Sevana (Ahara, Vihara \& Manosambandhi Nidana), increases its amount and then reaching Raja carrying vessels (branches of ovarian and uterine arteries) of the uterus, increases immediately the amount of Raja (Artava or menstrual blood). Vitiation of Tridosha leads to Agnimandyata which leads to Vikrit Ahara Rasa Nirmana and Rasagni Vaishamya \& due to this Vikrit Rasa Dhatu Nirmana takes place. Artava being Upadhatu of
Rasa is also vitiated and because of this vikrit artava pramana vriddhi occur which affect the GarbhashayagataSira (Uterine Congestion/ Increased uterine circulation) which leads to Apana Vayu Dushti and Atyadhik and Chiarakala Artavastrava (Asrigdara) ${ }^{13}$. The general principles of treatment of bleeding per vaginum as follows- Dosha Shodhana and Shamana, Rakta-Sthapana \& Sangrahana, Use of Tikta Rasa and Eradication of the cause ${ }^{14}$. Considering this principle of treatment, Kutajashtaka Avaleha and Yashtimadhu Ghrita Matra Basti has been selected for the clinical trial. Both the formulations have Deepana, Pachana, Rakta-Sthapana and Rakta-Sangrahana, Kashaya, Tikta and Madhura 
Rasa, Garbhashaya Balya, Vatanulomana, Shothahara and Grahi effect. Basti therapy is considered as Prime among all the therapeutic measures specially for the management of Vata-Vyadhies. Our Acharyas have considered the Guda (rectum) as the root of the body (Shariramoola). On the action of Basti, Vagabhata says that Virya of Basti is conveyed to Apana and then to Samana Vata, which may regulate the function of Agni. It then goes to Udana, Vyana and Prana, thus providing its efficacy all over the body. At the same time Basti by pacifying Vata, restores the disturbed Kapha and Pitta at their original seats and thus helps in breaking the pathogenesis. Yashtimadhu Ghrita was used for Matra basti. Yashtimadhu (Glycyrrhiza glabra) is having Madhura Vipaka, Sheeta Virya, Madhura Rasa, Shothahara and Garbhashaya Balya properties ${ }^{15}$. Ghrita alleviates vata, pitta and toxic conditions from the body. It is the best of all the unctuous substances. It is having sheeta virya, madhura rasa and madhura vipaka. Old Cow ghee is useful in intoxication as well as for disorders of female genital tract ${ }^{16}$.

\section{Effect of therapy on Subjective parameters-}

Duration of Bleeding: Kutaja, Mochrasa, Ativisha, Dhataki and Bilva have Upshoshana, Grahi and Stambhana properties \& Madhura Rasa of Yashtimadhu and Ghrita, which alleviates Vata and Pitta hereby reducing the duration of bleeding.

Intermenstrual period: Most of the Drugs having deepana, pachana property which improves the status of Agni and correct Agnimandyata. Kutaja, Mochrasa, Ativisha, Bilva and Dhataki have Upshoshana, Grahi and Stambhana properties ${ }^{17}$, so it has reduced the intermenstrual bleeding. Sheeta Virya of Yashtimadhu and Ghrita pacifies Pitta dosha which is responsible for repeated and intermenstrual bleeding.

Low Backache \& Lower Abdominal Pain: It was due to Analgesic Property of Kutaja, Mochrasa \& Musta help in alleviating the Low Backache and Lower Abdominal Pain. Aggravated Vata Dosha (which causes vitiation of rakta \& pitta) is pacified by Snigdha and Guru guna of Madhura rasa (Yashtimadhu and Ghrita), hence reducing the Low Backache and Lower abdominal pain.

Amount of Blood Loss: Anti-inflammatory property of Yashtimadhu reduces the Amount of blood loss by reducing the congestion in uterine vessels ${ }^{18}$. Patha, Lajjalu and Musta have Shodhana and Shothahara properties so it has reduced the amount of blood loss by reducing the congestion in uterine vessels ${ }^{19}$.

\section{CONCLUSION}

Kutajashtaka Avaleha orally alone and Combination of Matra Basti with Yashtimadhu Ghrita \& Kutajashtaka Avaleha oral both gave highly Significant results $(\mathrm{p}<0.001)$ in the management of Asrigdara with better results when the treatment was combined. Treatment given to the patients in both the Groups has markedly improved (51-75\% relief) the signs and symptoms of Asrigdara. Overall effect of therapy between the Groups revealed that the Mean \% reduction in all the five subjective parameters in Group B was more (63.75\%) as compared to Group A (58.40\%). Matra Basti also helped in regularization of Apana Vayu, thereby normalizing the flow of menstrual blood. Basti by pacifying Vata, restores the disturbed Kapha and Pitta at their original seats and thus helps in breaking the pathogenesis. On comparing the effect between the two groups, it can be concluded that the combination of Kutajashtaka Avaleha and Yashtimadhu Ghrita Matra Basti was found statistically more significant as compared to Kutajashtaka Avaleha given alone. No adverse effects were reported during the entire study period by any of the patients in either of the Group.

\section{REFERENCES}

1. Edlund M, Magnusson C, Von Schoultz B. Quality of life: A Swedish survey of 2200 women with DUB. London: Royal Society of Medicine Press, 1994: 36-37.

2. S.D. Harlow and O.M.R Campbell. "Menstrual dysfunction: a missed opportunity for improving reproductive health in developing countries". Reproductive Health Matters, 2000; Vol.8 (15): 142-147.

3. www.mayoclinic.org

4. Pt. Kashinath Shastri, Dr. Gorakhnath Chaturvedi, Commentary: Vidyotini Hindi Commentary On Charaka Samhita Of Agnivesha, Volume- 2, Chikitsa sthana, 30/209, Chaukhamba Bharti Academy, Varanasi, reprint $2015 ;$ p 868. 
5. Sushruta Samhita. Edited By AmbikaduttaShastri. Sharirasthana, 2/21, Chaukhambha Sanskrit Sansthan, Varanasi, reprint 2015; p 16.

6. Pt. Kashinath Shastri, Dr. Gorakhnath Chaturvedi, Commentary: Vidyotini Hindi Commentary On Charaka Samhita Of Agnivesha, Volume- 2, Chikitsa sthana, 30/207-209, Chaukhamba Bharti Academy, Varanasi, reprint 2015; p 868.

7. Indu. Commentary: Shashilekha, Sanskrit commentary on Ashtanga Sangraha, 38/45, Chaukhambha Sanskrit Series Office, Varanasi, Third Edition, reprint 2012; p 830

8. Valle RF. Rollerball endometrial ablation. Clin Obstet Gynaecol 1995; 9: p 299-316. Br J Obstet Gynaecol 1998, Vol.105, p 517.

9. Dr. Brahmananda Tripathi. Commentary: Dipika Hindi commentary on Sharangadhara Samhita, Madhyama khanda, 8/45, Chaukhamba Subharti Prakashan, Varanasi, reprint 2014

10. Sushruta Samhita. Edited By Ambika Dutta Shastri, Uttar tantra, 45/44, Chaukhambha Sanskrit Sansthan, Varanasi, reprint 2013; p 397

11. Katrina Wyatt, Paul Dimmock, Shaughn O'Brien, Caroline Kirkham, Gill Warrilow and Khaled Ismail. Quantification of menstrual blood loss. The Obstetrician \& Gynaecologist, 2004, DOI: 10.1576/toag.6.2.88.26983; p 88-92. onlinelibrary.wiley.com.

12. Pt. Kashinath Shastri, Dr. Gorakhnath Chaturvedi, Commentary: Vidyotini Hindi Commentary On Charaka Samhita Of Agnivesha, Volume- 2, Siddhi Sthana, 1/4445, Chaukhamba Bharti Academy, Varanasi, reprint 2013; p 972-973.

13. Pt. Kashinath Shastri, Dr. Gorakhnath Chaturvedi, Commentary: Vidyotini Hindi Commentary On Charaka Samhita Of Agnivesha, Volume- 2, Chikitsa Sthana, 30/206-207, Chaukhamba Bharti Academy, Varanasi, reprint 2013.

14. Sushruta Samhita. Edited By Ambikadutta Shastri. Sutra sthana, 15/21, Chaukhambha Sanskrit Sansthan, Varanasi, reprint 2015.

15. D.S. Lucas, Dravyaguna-Vijnana, Vol-2, Yashtimadhu: Study of Drugs in Detail, Chaukhamba Vishvabharati Publisher, Varanasi, 2013. P 102-105.

16. Pt. Kashinath Shastri, Dr. Gorakhnath Chaturvedi, Commentary: Vidyotini Hindi Commentary On Charaka Samhita Of Agnivesha, Volume- 1, Sutra Sthana, 13/14, Chaukhamba Bharti Academy, Varanasi, reprint 2013.
17. D.S. Lucas, Dravyaguna-Vijnana, Vol-2, Study of Drugs in Detail, Chaukhamba Vishvabharati Publisher, Varanasi, 2013.

18. Prof. Dr. Ali Esmail Al-Snafi. Glycyrrhiza glabra: A phytochemical and Pharmacological Review. IOSR Journal of Pharmacy, June 2018, Vol 8(6); p 1- 17.

19. D.S. Lucas, Dravyaguna-Vijnana, Vol-2, Study of Drugs in Detail, Chaukhamba Vishvabharati Publisher, Varanasi, 2013.

\section{Financial Support \& Sponsorship: Financial support} was given by All India Institute of Ayurveda, Sarita Vihar, New Delhi for conducting this clinical trial as a part of M.S.(Ayu.) thesis in the department of SRPT.

Conflicts of Interest: There are no conflicts of interest

How to cite this URL: Stuti Sharma \& Meenakshi Pandey: Management of Asrigdara With Kutajashtaka Avaleha And Yashtimadhu Ghrita Matra Basti-An Open Label, Double Arm, Randomized Clinical Trial. International Ayurvedic Medical Journal \{online\} 2020 \{cited October, 2020\} Available from: http://www.iamj.in/posts/images/upload/4701 4709.pdf 